Michael Y. Roleda · Dieter Hanelt · Christian Wiencke

\title{
Growth kinetics related to physiological parameters in young Saccorhiza dermatodea and Alaria esculenta sporophytes exposed to UV radiation
}

Received: 30 September 2004/ Revised: 15 December 2004/ Accepted: 16 December 2004/Published online: 18 February 2005

(C) Springer-Verlag 2005

\begin{abstract}
Young sporophytes of Saccorhiza dermatodea and Alaria esculenta cultured from Spitsbergen isolates were exposed in the laboratory to either only photosynthetically active radiation (PAR) or to a spectrum including UV-radiation (PAR + UVA + UVB) by use of cutoff glass filters. The plants were grown at $8 \pm 2^{\circ} \mathrm{C}$ and 16:8 h light-dark cycles with $6 \mathrm{~h}$ additional UV exposure in the middle of the light period. Growth was measured every $10 \mathrm{~min}$ using growth chambers with online video measuring technique for 18-21 days. Tissue morphology and absorption spectra were measured in untreated young sporophytes while tissue chlorophyll- $a$ content and DNA damage were measured from treated thalli at the end of the experiment. Under UVR, growth rates of $S$. dermatodea were significantly reduced while $A$. esculenta have a potential to acclimate. Tissue chlorophyll- $a$ contents in both species were not significantly different between treatments suggesting that these algae may acclimate to moderate UVR fluence. Higher DNA damage in $S$. dermatodea effectively diverted photosynthetic products for repair constraining growth. Tissue optics (opacity and translucence) was correlated to the tissue absorbance in the UVR region characteristics of phlorotannin, an important UV-absorbing compound in brown macroalgae. Growth rates of sporophytes of both
\end{abstract}

M. Y. Roleda $(\bowtie)$

Alfred Wegener Institute for Polar and Marine Research, Biologische Anstalt Helgoland, 27498 Helgoland, Germany E-mail: mroleda@awi-bremerhaven.de

Tel.: +49-4725-819230

Fax: +49-4725-819283

M. Y. Roleda

Biology Department, De La Salle University,

2401 Taft Avenue, 1004 Manila, Philippines

D. Hanelt

Biozentrum Klein Flottbek, University of Hamburg,

Ohnhorststr. 18, 22609 Hamburg, Germany

C. Wiencke

Foundation Alfred Wegener Institute for Polar and Marine Research, Am Handelshafen 12, 27570 Bremerhaven, Germany species exposed to PAR without UV was similar during day and night. The results showed that both species can recruit and inhabit a similar coastal zone when appropriate strategies are expressed to minimize damage in response to the stress factor.

\section{Introduction}

Saccorhiza dermatodea (Bachelot de la Pylaie) J. Agardh has a circumboreal distribution. It is found throughout the Arctic Ocean and extends down the northeastern seaboard of North America. Alaria esculenta (Linnaeus) Greville, on the other hand, is found in the North Atlantic as far south as the $16^{\circ} \mathrm{C}$ summer isotherm on the Brittany coast and extends north towards the Arctic (Lüning 1985). In Spitsbergen, S. dermatodea grows in the upper sublittoral while $A$. esculenta grows in the upper-mid sublittoral (Wiencke et al. 2004). However, they can also be found co-inhabiting a depth from $3 \mathrm{~m}$ to $10 \mathrm{~m}$ (Bischof et al. 1998).

Stratospheric ozone depletion is not only reported over Antarctica (Solomon 1999; Staehelin et al. 2001) but also over the Arctic (Jokela et al. 1993; Müller et al. 1997; Rex et al. 1997, 2002), which leads to enhanced levels of Ultraviolet-B radiation (UVBR) at the earth's surface. In aquatic ecosystems, reflection and attenuation within the water body reduces irradiance levels and alters spectral composition. However, biologically significant UVBR levels are still recorded down to 8-m water depth in Kongsfjorden (Hanelt et al. 2001).

Exposure to UV radiation (UVR) can significantly affect macrophyte productivity and ecophysiology (Franklin and Forster 1997). In particular, it can induce damage directly by photochemical degradation of biomolecules and cause DNA lesions forming cyclobutane-pyrimidine dimers (CPDs) or indirectly via the production of reactive oxygen species such as hydrogen peroxide and superoxide radicals, responsible for the more widespread oxidative damage within the cell 
(Vincent and Neale 2000). The resulting stress is manifested in increased energy demands for protection and repair, a decrease in growth rate resulting from the photochemical damage and disruption of cell metabolism and cell division, and under severe exposures, in mortality of the specimen.

UVR sensitivity of macrothalli of Laminariales is well documented (e.g. Clendennen et al. 1996; Aguilera et al. 1999; Karsten et al. 2001; Bischof et al. 2002a; Apprill and Lesser 2003). Most of these studies measured photosynthetic responses to UVR. In several studies (e.g. Hanelt et al. 1997a, b), sensitivity and recovery were found to be related to the depth distribution of the species while capability of acclimation is reported in upper sublittoral species (e.g. Bischof et al. 1998, 1999). However, acclimation of photosynthesis to UVR exposure cannot be equated to the ecological optimum of the plant because photosynthetic products are used for protection and repair, consequently constraining growth. For example, photosynthesis of Laminaria ochroleuca de la Pylaie is able to partially acclimate to chronic UVR exposure, but growth does not (Roleda et al. 2004a).

Different life stages of Laminariales are reported to be differentially susceptible to light stress (e.g. Dring et al. 1996; Hanelt et al. 1997c), whereby early developmental life stages are reported to be the most susceptible to UVR compared to the adult stages (reviewed by Coelho et al. 2000). For example, zoospore motility, germination capacity and DNA are affected under UVR (e.g. Huovinen et al. 2000; Wiencke et al. 2000, 2004; Makarov and Voskoboinikov 2001). A protective mechanism against UVR includes synthesis of the UVabsorbing compound phlorotannin (Schoenwaelder 2002; Wiencke et al. 2004).

Across a vertical gradient, growth of young sporophytes of the upper sublittoral S. dermatodea (Aguilera et al. 1999) and upper-mid sublittoral $A$. esculenta (Michler et al. 2002) is reported to be inhibited by UVR. Macroalgae growing in shallower depth are often more tolerant to UV and recover well after periods of high UV radiation. Morphologically, species with tougher and thicker thalli may also be less sensitive to UVR as a result of more protective tissue (Johansson and Snoeijs 2002).

In the present study, we compare growth kinetics of cultured young sporophytes under controlled laboratory condition and the potential for growth acclimation under UVR between $S$. dermatodea and A. esculenta using growth chambers with an automatic video growth measuring technique. Growth in terms of increase in pixel size will be measured at short time scales (e.g. every $10 \mathrm{~min}$ ) over a 3-week period. Data obtained from these measurements will allow us to quantify growth during and after UV exposures or during light and dark phases of the daily photoperiod. DNA damage accumulation and pigment content will also be measured after repeated exposure to UVR. The effect of UVR on growth will be discussed in relation to thallus morphology, tissue absorption spectra characteristics of UV-absorbing compounds and depth distribution of the sporophytes in the field.

\section{Materials and methods}

\section{Algal material}

Cultures of $S$. dermatodea and $A$. esculenta gametophytes (hereinafter called 'Alaria' and 'Saccorhiza' respectively), originally established from spores of fertile sporophytes collected by SCUBA diving in Kongsfjorden, Spitsbergen $\left(78^{\circ} 55^{\prime} \mathrm{N}, 11^{\circ} 56^{\prime} \mathrm{E}\right)$, were used to obtain young sporophytes. They were grown aerated in 51 culture bottles filled with Provasoli enriched seawater (Starr and Zeikus 1993) inside a temperature-controlled room at $8 \pm 2^{\circ} \mathrm{C}$ and $10 \mu \mathrm{mol}$ photon $\mathrm{m}^{-2} \mathrm{~s}^{-1}$ white light at 12:12 h light:dark photoperiod. To compare morphological differences between cultured and wild specimen, young sporophytes were collected by SCUBA diving in May 2004 in Kongsfjorden.

\section{Online video growth measurement technique}

Three growth chambers (ISITEC GmbH, Bremerhaven, Germany) with online video measuring technique described by Roleda et al. (2004a) were operated simultaneously in the experiment (Fig. 1a). Each growth chamber contained two basal pieces of thalli (average size $=30 \mathrm{~mm}^{2}, \pm 6 \mathrm{~mm}$ of the phylloid including the meristem), positioned $20-\mathrm{mm}$ apart from each other. They were fixed using tiny nails between the top and bottom of the UV-transparent Plexiglas chamber (Fig. 1b,c). The space between the top and bottom chambers allows circulating filtered, pasteurized and cooled seawater $\left(8 \pm 2^{\circ} \mathrm{C}\right)$ to pass through. Light sources are mounted $15 \mathrm{~cm}$ above the platform (Fig. 1d) consisting of two white fluorescent lamps (Philips, TL $8 \mathrm{~W} /$ 965, Holland) and two UV lamps (Q-Panel UVA-340, 40 Watt, Cleveland, USA; modified from the figure). Infrared diodes (wavelength $=930 \mathrm{~nm}$ ) are mounted at the sides of the chamber to produce infrared images of the object for the video camera, also during the dark periods. The captured image by the CCD camera (Fig. 1e) is analysed by a MedeaLAB Count and Classify software (Fig. 1f; Multimedia and Software GmbH, Erlangen, Germany) which measures growth, in terms of increased number of pixel, of the algae.

The algal samples were acclimated for 3 days inside the growth chambers to $16: 8$ light-dark photoperiod without UVR. After acclimation, UVR was supplemented in the middle of the light phase $(0900-1500 \mathrm{H})$. Two types of glass filters, Schott-GG 400 (Schott, Germany) and Quartz glass, were put on the top of the Plexiglas chamber, each covering one of the two algal samples, respectively. This corresponds to two treatments per chamber with photosynthetically active 
Fig. 1 a-f ISITEC growth chamber (a) showing UVtransparent Plexiglas chambers where the algae is fixed between the top (b) and bottom (c) of the chambers. Seawater inflow and outflow outlets are shown in the bottom part of the Plexiglas chamber. Lamps and infrared diodes (d) are mounted above the platform and on the sides of the growth chamber,

respectively. Image captured by the CCD camera (e) is analysed by MedeaLAB Count and Classify software, a measurement for one thallus piece is shown in (f)

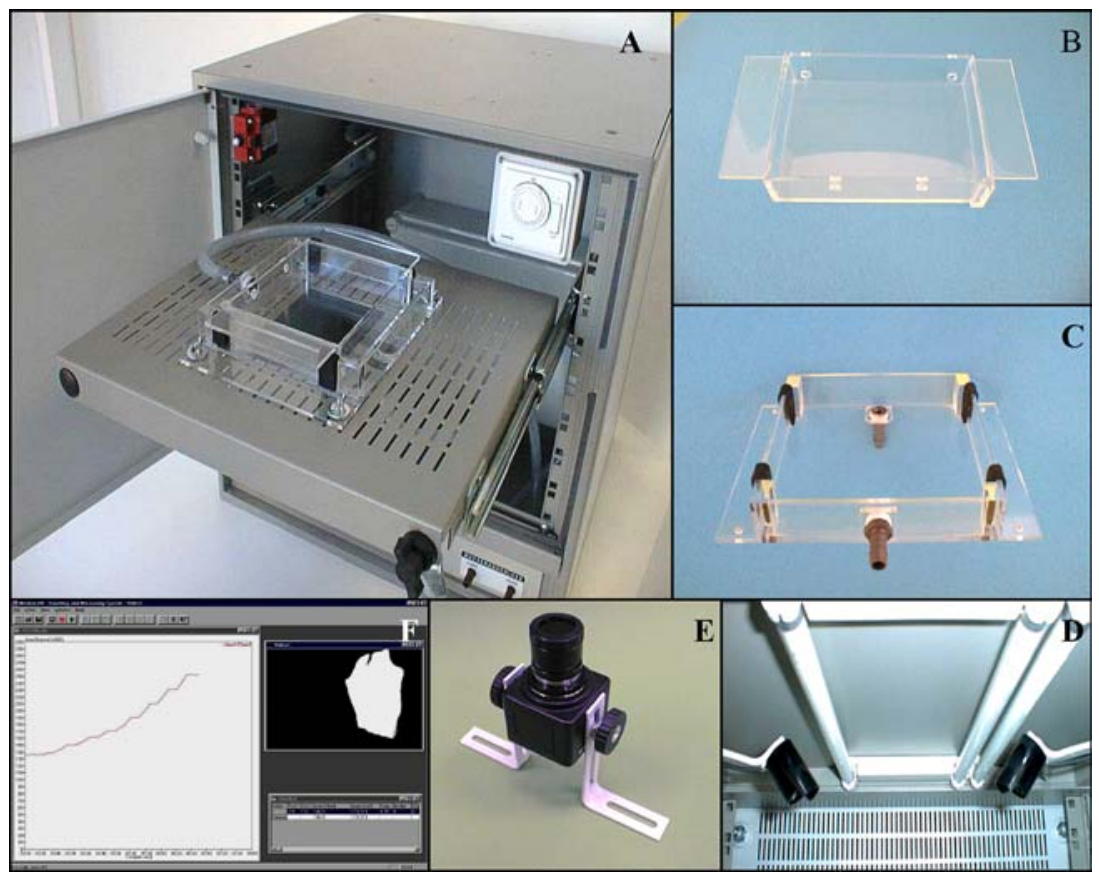

radiation $(\mathrm{PAR}=\mathrm{P})$ and $\mathrm{PAR}+\mathrm{UVA}+\mathrm{UVB}(\mathrm{PAB})$ treatment. The three growth chambers operated simultaneously per species, were used as replicates for the $\mathrm{P}$ and PAB treatments.

Irradiance was measured using a scanning UV-VIS spectrometer (M. Kruse, Bremerhaven, Germany) below the glass filters. Weighted irradiance was calculated using action spectra for well-known biological responses: DNA damage for Escherichia coli (280-320 nm, Setlow 1974) and the generalized plant damage (280$312 \mathrm{~nm}$ ) described by Caldwell (1971). Both unweighted and weighted irradiances for each treatment are compiled in Table 1. Growth was continuously measured every $10 \mathrm{~min}$ for $18-21$ days. Seawater was changed weekly to ensure enough nutrient supply within the medium. At the end of each growth experiment, algal thalli were transferred to 2-ml Eppendorf tubes and frozen at $-80^{\circ} \mathrm{C}$ for further chemical analyses.

Growth rate was computed by plotting all data points (entire experimental period) of each replicate per treatment. They were individually fitted to an exponential equation $N_{t}=N_{0} \mathrm{e}^{r t}$, where $N_{t}$ is growth at time $t, N_{0}$ is initial size and $r$ is the intrinsic rate of increase. Growth rate at time $t(r t)$ is comparable to the growth equation applied by Lüning (1979): relative growth rate $(\%$ day $\left.^{-1}\right)=\left(\ln \mathrm{SA}_{2}-\ln \mathrm{SA}_{1}\right) / t_{2}-t_{1} \times 100$, where $\mathrm{SA}_{1}$ and $\mathrm{SA}_{2}$ are the surface areas at $t_{1}$ and $t_{2}$ in days, respectively. To determine day and night growth rates, daily growth rates $\left(\% \mathrm{~h}^{-1}\right)$ during the light $(16 \mathrm{~h})$ and dark phase $(8 \mathrm{~h})$ of plants exposed to photosynthetically active radiation $(\mathrm{P})$ alone were computed using the same exponential equation. Mean day and night growth rates were computed every three days. Among sporophytes exposed to PAB (PAR + UVA + UVB), circadian growth rates and three days average $\left(\% \mathrm{~h}^{-1}\right)$ were computed during the start of the light phase without UV $(0500-0900 \mathrm{~h})$, in the middle of the light phase with UV supplement $(0900-1500 \mathrm{~h})$, at the end of the light phase without UV (1500-2100 h), and during the dark phase (2100-0500 h).

\section{Thallus morphology}

The wet weight: surface area $\left(\mathrm{mg}: \mathrm{mm}^{2}\right)$ ratio was used to determine thallus thickness (Roleda et al. 2004b).

Table 1 Unweighted and weighted irradiance applied in the growth chambers

\begin{tabular}{|c|c|c|c|c|}
\hline & \multicolumn{4}{|c|}{ Irradiance $\left(\mathrm{W} \mathrm{m}^{-2}\right)$} \\
\hline PAR (400-700 nm) & 3.60 & 4.00 & 0 & 0 \\
\hline UVA $(320-400 \mathrm{~nm})$ & 0.02 & 4.92 & 0 & 0 \\
\hline
\end{tabular}


Surface area of sporophytes taken directly from the unialgal cultures was measured using a scanner and WinFolia 5.0 image analysis software (Regent Instrument, Quebec City, Canada) and the corresponding wet weight of the blotted tissue was weighed using Sartorius (CP225D, Germany) weighing scale $(n=10)$.

\section{Absorbance spectrum}

To determine the presence of UV-absorbing compounds in the tissue, young sporophytes obtained from culture were inserted into seawater-filled quartz cuvettes and scanned with seawater as reference in the $250-700 \mathrm{~nm}$ waveband using a Shimadzu photometer (UV 2401PC, Japan) equipped with an integrating sphere. For comparison, young sporophytes collected in the field in Spitsbergen were also scanned.

Pigment extraction and characterisation

Frozen samples were treated with $100 \mu \mathrm{l}$ of $100 \% \mathrm{~N}-\mathrm{N}$ dimethylformamide and stored in darkness for approximately $16 \mathrm{~h}$. Subsequent analyses were performed using HPLC as described by Bischof et al. (2002b).

\section{DNA extraction and quantification}

Thalli were homogenized in liquid nitrogen and DNA was isolated following the CTAB extraction procedure described by Poll et al. (2001) and modified by Roleda et al. (2004b). After DNA extraction, the pellet was dissolved in $0.2 \mathrm{ml}$ TE buffer $(10 \mathrm{mM}$ Tris, $1 \mathrm{mM}$ EDTA, pH 8.0), treated with RNAase $\left(5 \mu 10 \mathrm{mg} \mathrm{ml}^{-1}\right.$, $30 \mathrm{~min}, 37^{\circ} \mathrm{C}$; Sigma, MO) and stored at $-20^{\circ} \mathrm{C}$. The DNA concentration was quantified fluorometrically using PicoGreen assay (Molecular Probes, Eugene, OR) and a Cary Eclipse Fluorescence Spectrophotometer (Variance Scientific Instrument, CA). A dilution series with a known amount of DNA (Serva, Heidelberg, Germany) was included for calibration purposes.

\section{Assay for CPDs detection}

The immunoassay for CPDs was modified after Vink et al. (1994) and Poll et al. (2001). Heat-denatured samples containing $50 \mathrm{ng}$ DNA were transferred to a nitrocellulose membrane (Protran BA 79, pore size $0.1 \mu \mathrm{m}$, Schleicher Schuell). After a two-step antibody assay, the membrane was treated with ECL Western blotting detection reagent (Amersham Buckinghamshire, UK) and sealed in a transparent vinyl plastic folder (Leitz, Stuttgart, Germany). This was subsequently exposed to photosensitive ECL films (Amersham) at different exposure time. The films were developed using X-ray film developer. Developed films were scanned using a Biorad imaging densitometer (Model GS-700, Bio-Rad Laboratories, USA) and gray scale values were quantified using Multi-Analyst (Macintosh Software for Bio-Rad's Image Analysis Systems). A calibration series of UV-irradiated calf thymus DNA (Serva) supplemented with unexposed DNA was included giving $1 \mu \mathrm{g} \mathrm{ml}^{-1}$ DNA for each calibration point. The UV-irradiated DNA was previously calibrated against UV-irradiated Hela DNA with known amounts of CPDs (kindly provided by A. Vink). CPDs were quantified by comparing the gray scales within the linear range of the film.

\section{Data analysis}

The statistical significant differences between treatments ( $\mathrm{P}$ versus $\mathrm{PAB})$ and between species (Saccorhiza versus Alaria) were tested using $t$-test $(P<0.05)$ using SPSS software (SPSS, Chicago, IL, USA).

\section{Results}

The intrinsic rate of increase $(r)$ in the surface area of both species exposed to $\mathrm{P}$ was higher compared to sporophytes exposed to PAB (Fig. 2). However, a significant effect of the treatment was only observed in the growth rate of Saccorhiza $(P=0.006)$ while growth rate of Alaria was not significantly different between treatments $(P=0.275$; inset Fig. 2$)$. Among sporophytes exposed to $\mathrm{P}$ only, average growth rates during the light and dark phase of the photoperiod was not different in Alaria throughout the whole experimental period while slightly higher growth rates during the light phase were observed in Saccorhiza from the 15th to the 18th day of measurement (Fig. 3). Among sporophytes exposed to the full light spectrum (PAB), a circadian growth pattern was observed (Fig. 4). Growth rates were mostly lowest in the morning $(0500-0900 \mathrm{~h})$ and at the middle of the light phase with UVR supplement (0900-1500 h). Growth rates increased in both species after UVR was switched off in the afternoon and during the dark phase in Alaria while variable growth pattern was observed during the dark phase in Saccorhiza. Comparison between species showed no significant difference in growth rates at the start of the light phase (0500-0900 h). In the middle of the light phase with UVR supplement, significant difference between species was only observed on the 18th day where growth rate of Saccorhiza was significantly depressed $(P<0.05)$. The same trend was observed at the end of the light phase (1500-2100 h) and at night, when Alaria showed significantly higher growth rates $(P<0.05)$. Time series observation on the growth rates of sporophytes during UVR exposure (0900$1500 \mathrm{~h}$ ) showed acclimation in the growth rate of Alaria and continuous decrease in the growth rate of Saccorhiza (Fig. 5). 


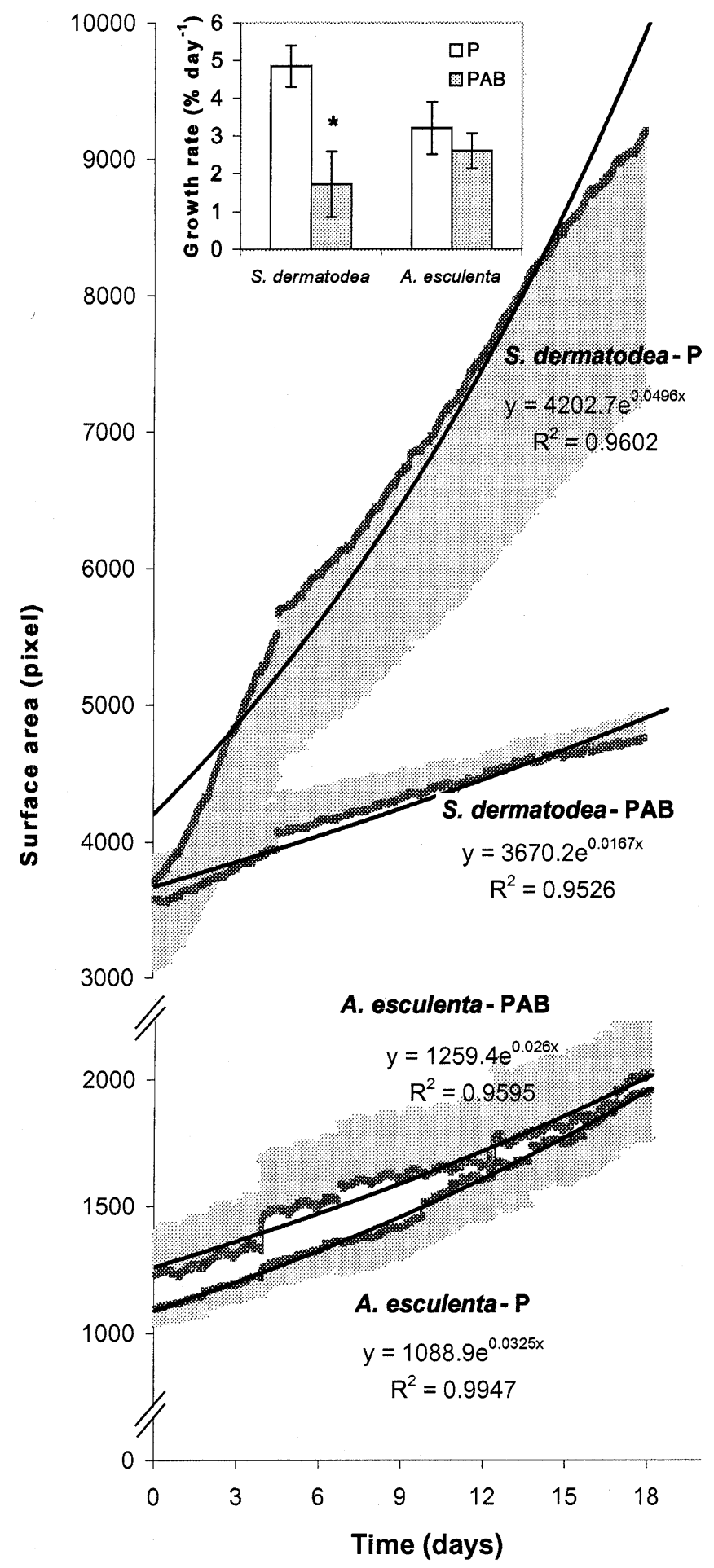

Fig. 2 Growth, in terms of surface area increase, in young sporophytes exposed to different irradiances of photosynthetically active radiation $(\mathrm{PAR}=\mathrm{P})$ and $\mathrm{PAR}+\mathrm{UVA}+\mathrm{UVB}(=\mathrm{PAB}) . \mathrm{PFD}$ was $\pm 20 \mu \mathrm{mol} \mathrm{m}{ }^{-2} \mathrm{~s}^{-1}$. Data points (irregular dark gray points) are fitted using the exponential growth equation $N_{t}=N_{0} \mathrm{e}^{r t}$ (dark solid curves), where $N_{t}$ is growth at time $t$ and $N_{0}$ is initial size. Values are means $\pm \mathrm{SD}$ (light gray one sided area, $n=3$ ). Inset is the corresponding growth rates for the entire experimental period. * refers to significant differences between mean values ( $t$-test, $P<0.05)$
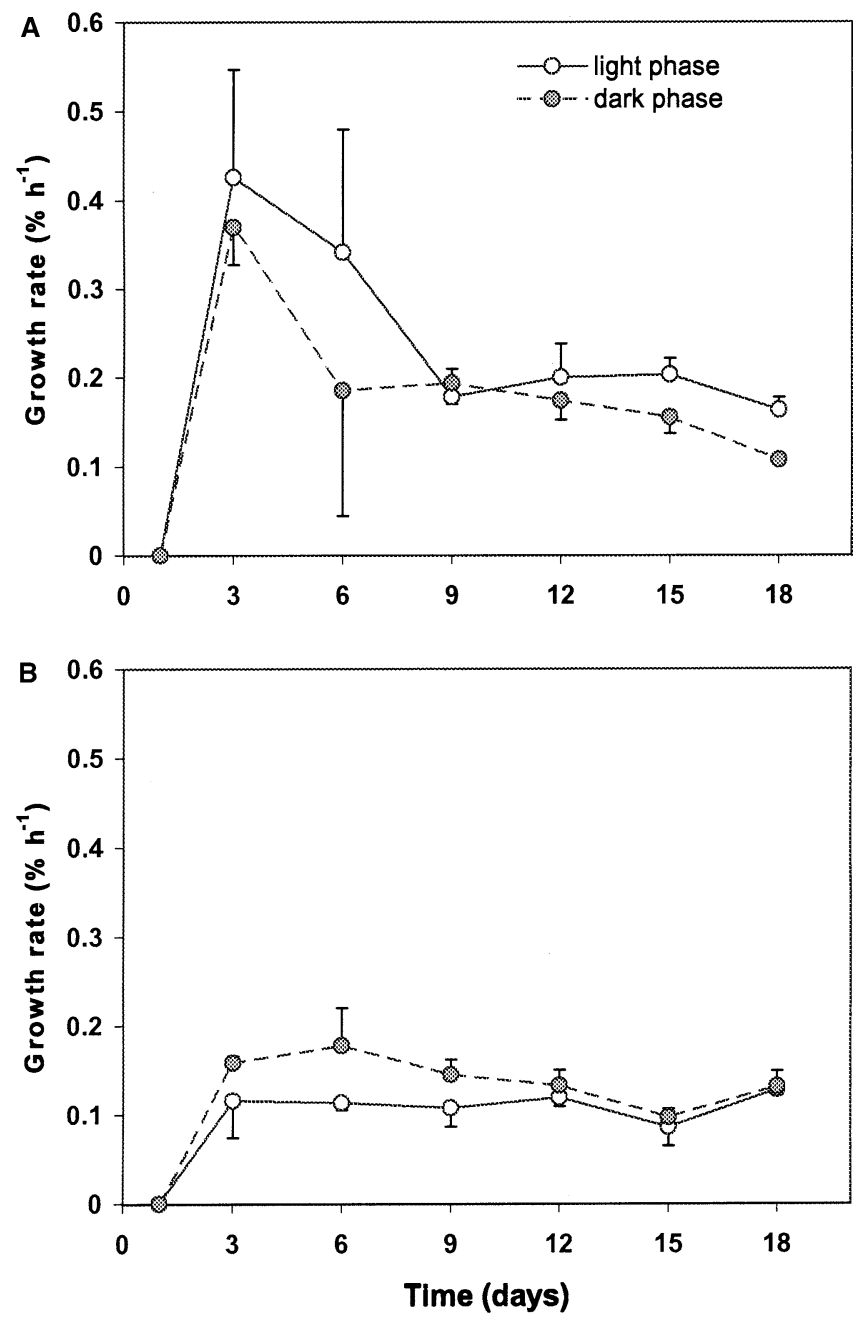

Fig. 3 a, b Growth rates of young sporophytes exposed to photosynthetically active radiation $(\mathrm{PAR}=\mathrm{P})$ during the light $(16 \mathrm{~h})$ and dark phase $(8 \mathrm{~h})$ of the photoperiod in (a) Saccorhiza dermatodea and (b) Alaria esculenta

Cultured sporophytes grown in low white light without UVR showed that Saccorhiza had thicker thalli compared to Alaria $(P<0.0001 ;$ Fig. 6a). Different growth forms were observed between wild and cultured sporophytes (insets Fig. 7a,b). The collected wild Saccorhiza specimen already exposed to naturally high solar radiation was more robust and pigmented compared to the cultured specimen. Alaria cultured at daylength of 12 or $16 \mathrm{~h}$ was darkly pigmented and opaque compared to the translucent wild specimen. When transferred from $12 \mathrm{~h}$ to $24 \mathrm{~h}$ daylength, the thalli become lightly pigmented and translucent after 2 weeks (Fig. 7b). However, cultured Alaria manifest broader thalli compared to the more tapered wild specimen with a very distinct midrib. Significantly higher chlorophyll- $a$ concentration was measured in Alaria compared to Saccorhiza $(P<0.05)$. Comparison between treatments, however, showed only slightly and insignificantly higher chl $a$ concentration in sporophytes exposed to PAB compared to $\mathrm{P}$ (Fig. 6b). DNA damage measured as the number of 
Fig. 4 Average circadian growth pattern of young sporophytes exposed at the start of the light phase to PAR without UV (0500-0900 h); in the middle of the light phase with UV supplement $(0900-$ $1500 \mathrm{~h}$ ); at the end of the light phase again without UV (1500$2100 \mathrm{~h}$ ); and during the dark phase $(2100-0500 \mathrm{~h}) .{ }^{*}$ refers to significant differences between mean values $(t$-test, $P<0.05)$
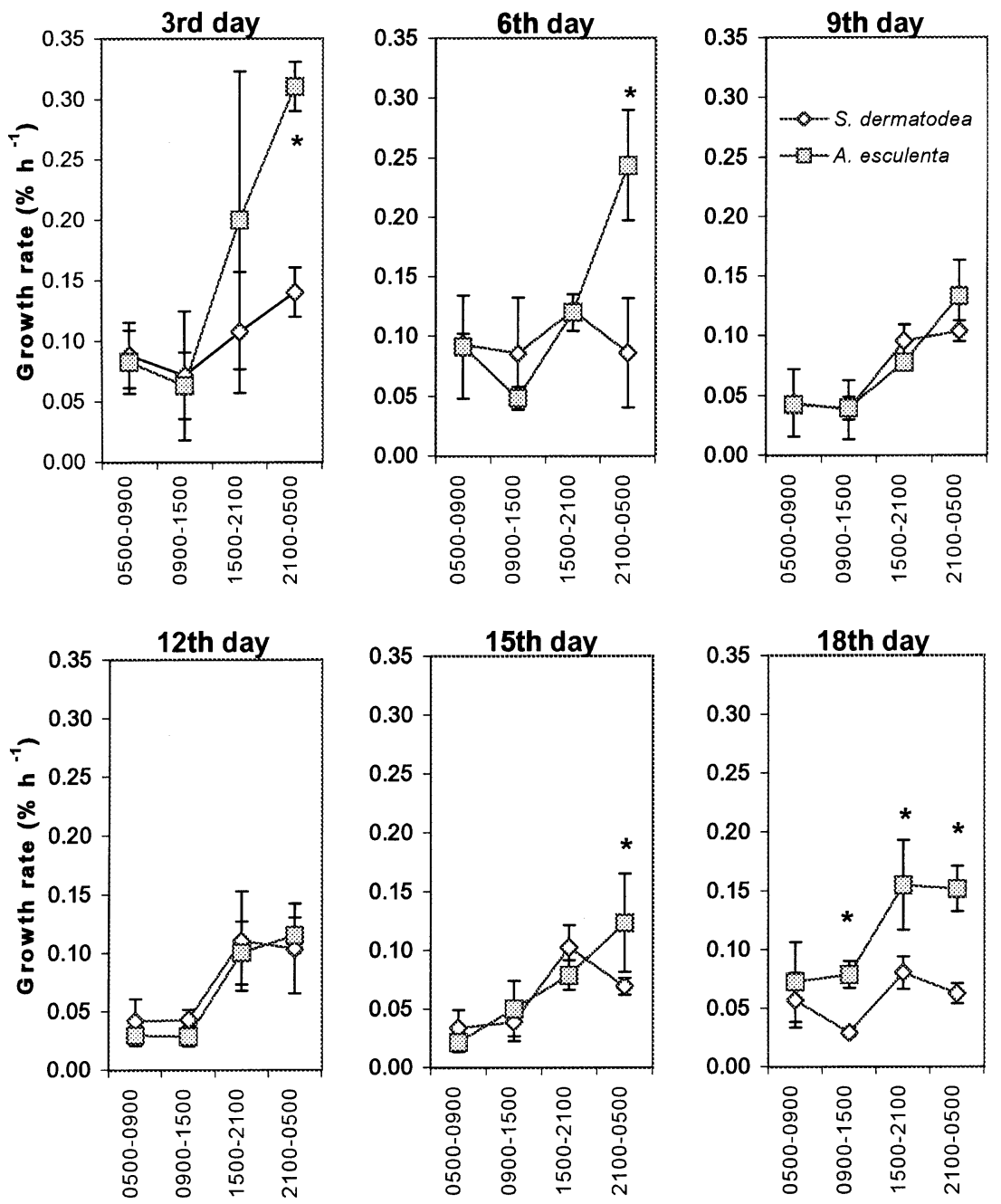

Time of day

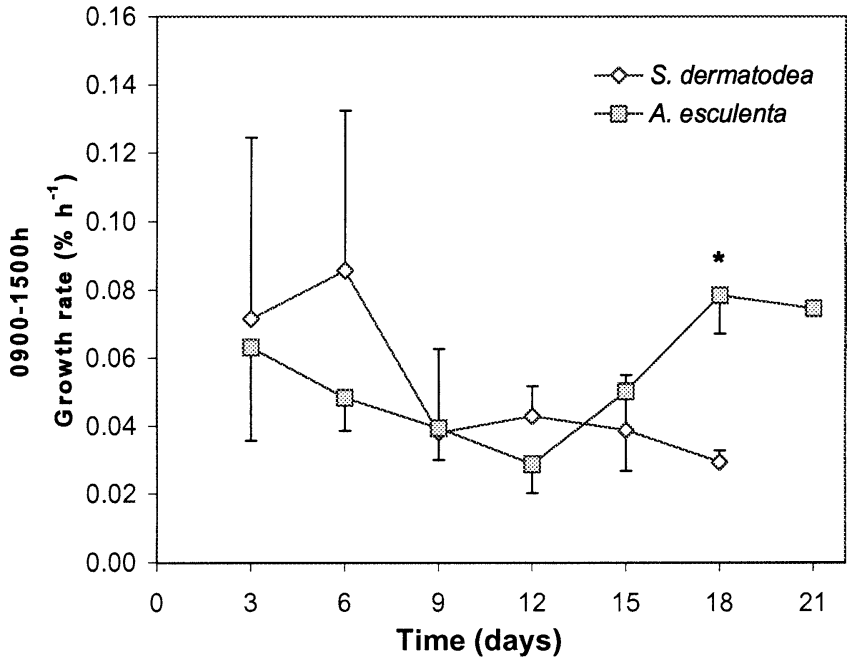

Fig. 5 Average growth rates monitored over a period of 21 days in young sporophytes of Saccorhiza dermatodea and Alaria esculenta during UVR exposure $(0900-1500 \mathrm{~h})$. * refers to significant differences between mean values $(t$-test, $P<0.05)$ cyclobutane pyrimidine dimers (CPDs) showed significantly higher DNA damage induction and CPDs accumulation in Saccorhiza compared to Alaria $(P<0.0001$; Fig. 6c). Spectral analysis of tissue showed different absorbance between the wild and cultured young gametophytes. The absorbance maxima observed in the UVR region are characteristic for the phlorotannin absorption spectrum. Strong absorption below $280 \mathrm{~nm}$ was measured in the wild Saccorhiza compared to the cultured sporophytes (Fig. 7a). Cultured Alaria grown at $12 \mathrm{~h}$ and experimentally exposed to $16 \mathrm{~h}$ daylength were opaque. These samples showed a very strong absorption below $360 \mathrm{~nm}$ while collected wild and cultured sporophytes grown at $24 \mathrm{~h}$ daylight showed similar but much lower absorbance spectra with maximal absorbance below $280 \mathrm{~nm}$ (Fig. 7b).

\section{Discussion}

Potential for growth acclimation in young sporophytes to UVR was found to be specific for one of the inves- 


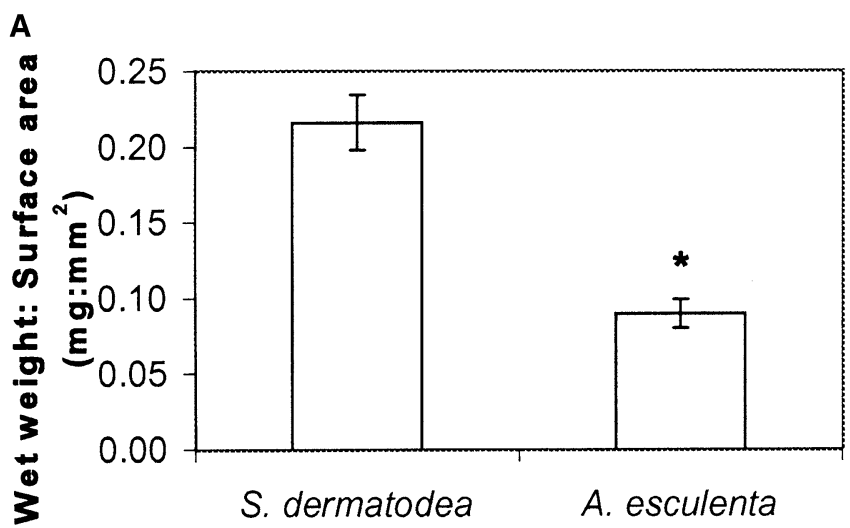

B
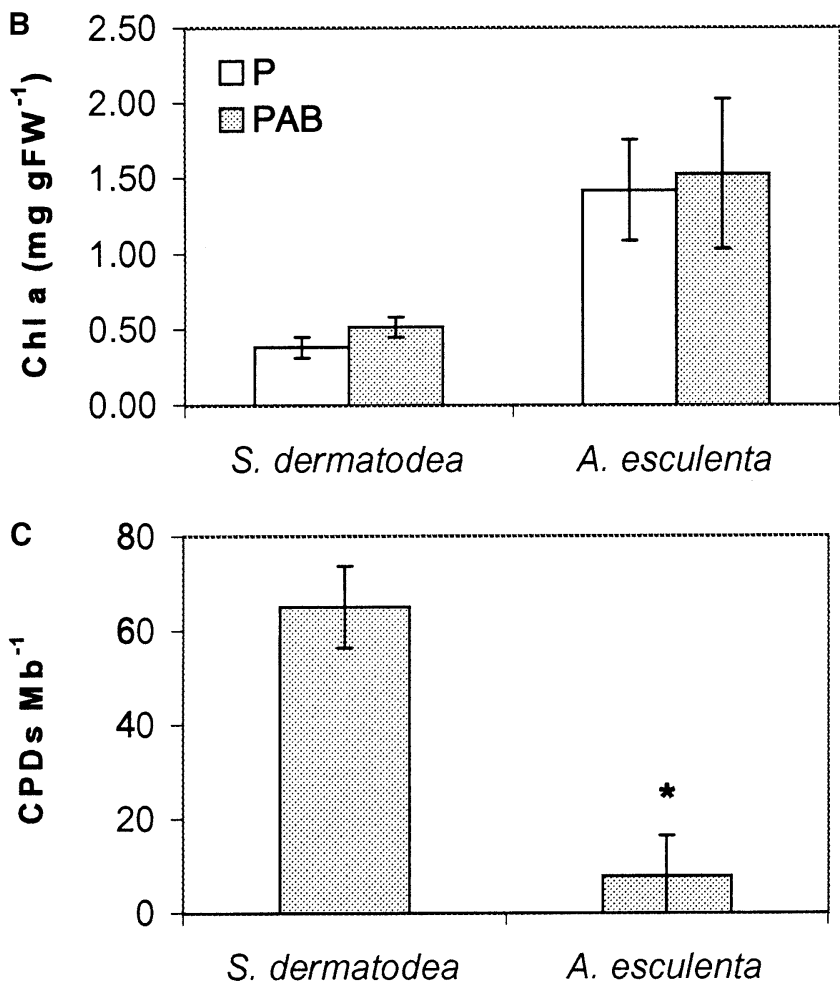

Fig. 6 a-c Morphological and biochemical characteristics in young sporophytes of Saccorhiza dermatodea and Alaria esculenta where (a) Surface area: wet weight ratio to determine thallus thickness of cultured sporophytes $(n=10)$; (b) Chlorophyll- $a$ content in sporophytes exposed to photosynthetically active radiation $(\mathrm{PAR})=\mathrm{P}$ and $\mathrm{PAR}+\mathrm{UVA}+\mathrm{UVB}=\mathrm{PAB}(n=3) ;(\mathbf{c}) \mathrm{UVB}$-induced DNA damage measured as cyclobutane pyrimidine dimers (CPDs) concentrations per million nucleotides $(n=3)$. Vertical bars are standard deviations (SD). * refers to significant differences between mean values $(t$-test, $P<0.05)$

tigated species and correlated to tissue DNA damage induction and CPDs accumulation while tissue chlorophyll- $a$ contents in both species were able to acclimate to moderate UVR fluence. Higher DNA damage diverts photosynthetic products for repair, thus constraining growth. Moreover, we found that thallus optical property was correlated to the tissue absorbance in the UVR region, characteristic of phlorotannin, an important UV-absorbing compound in brown macroalgae. This study showed that appropriate stress protective response
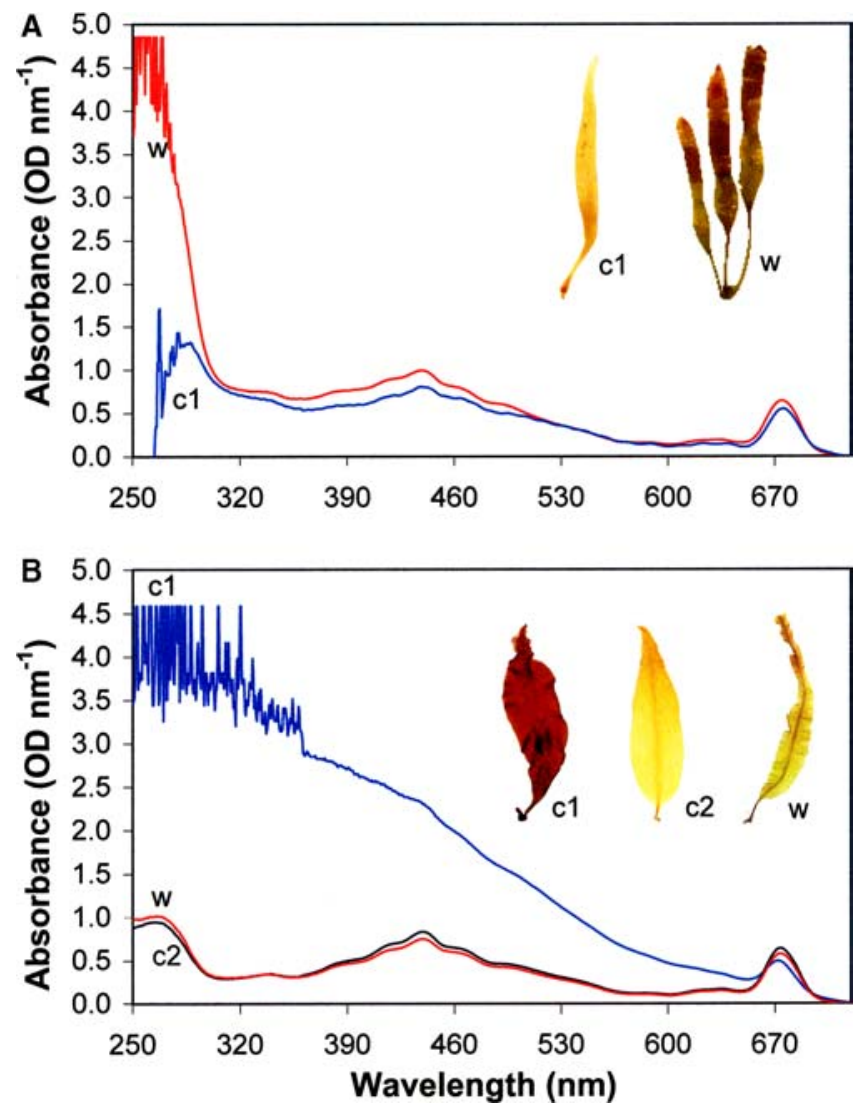

Fig. 7 a,bTissue absorbance spectrum of cultured $(\mathrm{cl}=12-16 \mathrm{~h}$ daylength; $\mathrm{c} 2=24 \mathrm{~h}$ daylength) and wild (w) young sporophytes in (a) Saccorhiza dermatodea and (b) Alaria esculenta. The insets show photographs of the typical morphology of thalli used for the experiments

such as synthesis of phlorotannin, and efficient DNA damage repair mechanism can enhance survival of young recruits and may be a factor for the determination of the upper distribution range of a species.

Previous studies on the same species have shown that photosynthesis of Alaria acclimate to UVR (Bischof et al. 1999) while photosynthesis of Saccorhiza is photoinhibited under full solar spectrum (Karsten et al. 2001). In our study, we found that growth responds similarly to photosynthesis. Outdoor incubation of Saccorhiza to the natural solar radiation also showed the same growth inhibition under UVR (Aguilera et al. 1999). On the other hand, previous study on the growth of Alaria under laboratory condition showed contrasting result where significantly lower growth rate was observed in sporophytes exposed to UVR (Michler et al. 2002). This is attributed to the different parts of the sporophytes used in the experiment. In the present study, we used acclimated meristematic basal parts of the young sporophytes while Michler and co-workers used cut off pieces from the meristem of the blade, making the wounded tissue more susceptible to UVR.

UVB-R induced DNA damage can be repaired through photoreactivation or excision repair (Karentz 1994; Pakker et al. 2000a, b; Poll et al. 2002). However, 
when DNA damage rate is higher, photosynthetic products will be diverted to cellular repair at the expense of growth and reproduction. Difference in thallus morphology, such as thickness, maybe regarded as protective mechanism against both high PAR and UVR in macroalgae (Dring et al. 1996; Hanelt et al. 1997c; Johansson and Snoeijs 2002). However, CPDs concentration was higher in the thicker Saccorhiza thallus suggesting that DNA damage rate exceeds repair rate in this species. Thallus thickness in itself is therefore not sufficient to minimize deleterious UVR effects. The optical property of the thallus is also important, which can influence reflection, attenuation, scattering, absorption or transmittance of UV radiation in plant tissues (Caldwell et al. 1983). To prevent UVR induced damage, many macroalgae produce UV screening compounds such as phlorotannins in brown macroalgae (Pavia et al. 1997; Pavia and Brock 2000; Schoenwaelder 2002; Henry and Van Alstyne 2004). In comparison to isolated phlorotannins from Fucus gardneri (Henry and Van Alystyne 2004), the absorbance spectrum of Alaria and Saccorhiza tissues showed a similar strong absorption in the UV-C and UV-B region. In terrestrial plants, wavelength selectivity of absorption in leaf epidermis is very pronounced and is often attributed to flavonoids and other related UV-absorbing compounds (Robberecht and Caldwell 1978). Phenolic compounds generally have substantial UV absorbance and very little absorption in the visible waveband (Caldwell et al. 1983).

Trade-offs between phlorotannin production and growth were observed in Ascophyllum nodosum (Pavia et al. 1999). Although phlorotannin concentration was not quantitatively analyzed in our study, the absorbance maxima in the UVR region of the tissues are characteristic of the phlorotannin absorption spectrum, showing higher concentration in cultured Alaria compared to Saccorhiza. The physiological cost of producing this UV-absorbing compound may be seen in the lower growth rate of Alaria compared to Saccorhiza. Alaria grown at $24 \mathrm{~h}$ daylength simulating polar day increased their growth rate to $11 \pm 3 \%$ day $^{-1}$ (data not shown) compared to only $3 \pm 1 \%$ day $^{-1}$ growth rate (Fig. 1) at 16:8 h light-dark photoperiod. An increase in growth rates to longer photoperiod was previously reported in A. esculenta from the British Isles (Han and Kain 1996).

The wild young Saccorhiza sporophytes, which were collected during the polar day in May in the upper sublittoral (4 m), were already exposed to higher natural solar UV radiation compared to wild young Alaria sporophytes, which were collected in the mid sublittoral (5-6 m) under the canopy of adult plants. At this point, wild young Saccorhiza sporophytes have already responded to the environmental cue by means of physiological mechanism to reduce stress such as synthesizing UV-absorbing compounds as shown in the darkly pigmented thallus of the wild isolate and the corresponding strong tissue absorption in the UVR region. On the other hand, recruitment of Alaria under the canopy of adult plants is thought to be an adaptive behavior which effectively protects these early life stages from stress factors, therefore minimizing ecological cost for defense, enabling the juvenile plants to allocate more photosynthate for growth (Herms and Mattson 1992). The expression of dark pigmented Alaria phenology in culture $(12$ or $16 \mathrm{~h}$ daylength of low white light, 10 $20 \mu \mathrm{mol}$ photon $\mathrm{m}^{-2} \mathrm{~s}^{-1}$ ) is speculated to be some kind of physiological mechanism (Roy 2000) related to the seasonal variation of daylength. It is typical for the so called season anticipators (Kain 1989). In these species, seasonal development is finely tuned to the seasonal variation of daylength and this strategy is evident from the organism to the cellular and metabolic level (Wiencke 1990a, b; Lüder et al. 2001, 2002; Dummermuth and Wiencke 2003). When unprotected juvenile recruits (such as in our unialgal culture) start growing during the short daylength (e.g. at the end of the polar night, before the start of polar day in the field), we hypothesize that the young sporophytes are investing UV-absorbing compounds in anticipation of the polar days when they could be potentially exposed to enhanced solar radiation. When we increased the daylength to $24 \mathrm{~h}$ depleted of UVR, the plants responded by growing faster and stopped synthesizing UV-absorbing compounds as shown in the decreased tissue absorbance in the UVR region supporting our hypothesis.

In zoospores, phlorotannin containing physodes was observed in both species. Enlargement of these phenolic vesicles was observed after $20 \mathrm{~h}$ exposure to PAR + UVA + UVB, which provide protective function against UVR (Wiencke et al. 2004). More prominent physodes were observed in Saccorhiza compared to Alaria spores, which consequently enhanced germination rate in $\mathrm{Sac}$ corhiza (Wiencke et al. 2004). Allocation of phenolic compounds seems to be dependent on life stage and life history of the plant. However, among $1-\mu \mathrm{m}-$ to $<10$ $\mu \mathrm{m}$-size class cells, production of UV-absorbing compounds can afford considerable benefits but only at the expense of relatively heavy energetic investment (GarciaPichel 1994). Phlorotannin synthesis in juvenile recruits lowers growth rate but could enhance survival of the young sporophytes. In adult sporophytes, higher concentrations of phenolic compounds are found in the reproductive fronds (sporophylls) than in the vegetative blades of the intertidal A. marginata Postels \& Ruprecht (Steinberg 1984) where sporogenic tissue could provide protection to zoospore containing sporangium against environmental stress factors. A conceptual model of the evolution of plant defense suggest that plant physiological trade-offs (e.g. allocation of photosynthate for repair, growth and reproduction, synthesis of UVabsorbing compounds and secondary metabolites) interact with the abiotic environment, competition and herbivory (Herms and Mattson 1992).

Seasonal variation in pigment concentration of Arctic Saccorhiza collected before, during and after sea ice break-up showed decreasing chlorophyll- $a$ concentration coinciding with the increasing underwater radiation (Aguilera et al. 2002). In the laboratory, we observed no 
significant variation in Chl- $a$ concentration between sporophytes exposed to the whole spectrum and to PAR alone. This could be attributed to the higher natural solar radiation at 3-4 m depth where Aguilera and coworker collected their algal material. In Ulva rigida C. Agardh, however, significantly higher pigment content (Chl $a$, Chl $b$ and carotenoids) was measured in the presence of UVB, which is speculated to be some kind of photoprotective mechanism (Altamirano et al. 2000). In Palmaria decipiens (Reinsch) Ricker, chlorophyll- $a$ concentration increases after $4 \mathrm{~h}$ of exposure to UVR. Further exposure to $12-16 \mathrm{~h}$ of UVR showed no significant variation between treatments (Poppe et al. 2002). This indicates the capability of algae to acclimate to moderate fluences of UV radiation.

Circadian (daily) rhythm in gene expression, cell division timing, photosynthesis and growth has been reported in algae (e.g. Lüning 1994a, 2001; Granbom et al. 2001; Suzuki and Johnson 2001; Jacobsen et al. 2003). Seasonal growth pattern in Laminariales is shown to be environmentally as well as internally controlled (Lüning 1993, 1994b). On a shorter time scale, day and night kinetics (diurnal pattern = within $24 \mathrm{~h}$ ) is also observed (Lüning 1992). Among Laminariales, study on growth kinetics has been performed in Laminaria spp. and Pterygophora californica Ruprecht, but not on $A$. esculenta and $S$. dermatodea. Maximal growth rate of $0.7 \% \mathrm{~h}^{-1}$ is reported in young Laminaria saccharina (Linnaeus) J.V. Lamouroux sporophytes (Lüning 1992), higher than the $0.42 \pm 0.1 \% \mathrm{~h}^{-1}$ growth rate that we observed in Saccorhiza. Lüning (1994a) further reported an immediate decrease in growth rate after the onset of darkness. This contradicts our study, which showed no significant difference in the growth rate between day and night in Alaria while lower growth rate at night was only observed later (day 15-18) in Saccorhiza. Apical growth of Ascophyllum nodosum and Chondrus crispus during the night makes up $33 \%$ and $63 \%$ of their average day growth rates, respectively (Strömgren and Nielsen 1986). In UVR-exposed Alaria sporophytes, higher growth rates even occurred during the dark phase, compared to the early morning and late afternoon light phase without UVR. It has been hypothesized that the driving force for the early evolution of circadian clocks could be an inherent advantage in phasing cellular events that are inhibited by sunlight to occur in the night (Suzuki and Johnson 2001). If this regulation by a circadian clock is adaptive, growth during the day in the absence of UV stress may be enhanced equal to but not greater than the growth at night.

Growth kinetics is thought to be species-specific, otherwise the contradicting result could be attributed to technical limitations of the image analysis software previously used by Lüning or to the interpretation of data wherein the author interpreted thallus area as 'single projected area' (Lüning 1992) and not as the total surface area. Our advanced image analysis software is able to measure the whole surface area continuously in the course of several days without interruption. Mea- surements are manually stopped for a maximum of $2 \mathrm{~h}$ to change the seawater in the circulating system every week.

For future studies, an in situ growth kinetics measurement is recommended. Prototypes of field growth chamber with similar growth measuring technique are currently developed for future use. Synergistic effects of abiotic factors will bring new insights on how growth mechanics operate in the field. The single factor laboratory experiment performed in this study has shown that growth is inhibited by UVR. Recovery of growth was observed after the offset of the stress factor and growth acclimation under UVR was observed in Alaria. UVR sensitivity in the growth rate of Saccorhiza is attributed to the accumulation of tissue DNA damage and the lower UV-absorbing compound concentration in cultured sporophytes. The potential of some species to acclimate to increased solar radiation is indicated by the changes in the optical properties of the leaf (Caldwell et al. 1983) or in the thallus of macroalgae as exhibited by Alaria. In the field, both species are capable of recruiting the upper sublittoral when appropriate physiological strategies are expressed to minimize UV-induced damage, as adult sporophytes could be found to inhabit the same coastal zone in Spitsbergen.

Acknowledegments The first author is supported by a scholarship from the German Academic Exchange Service (DAAD). We thank A. Gruber for collecting field materials and C. Daniel for pigment analysis. This is publication awi-n 14975 of the Alfred Wegener Institute for Polar and Marine Research.

\section{References}

Aguilera J, Karsten U, Lippert H, Vögele B, Philipp E, Hanelt D, Wiencke C (1999) Effects of solar radiation on growth, photosynthesis and respiration of marine macroalgae from the Arctic. Mar Ecol Prog Ser 191:109-119

Aguilera J, Bischof K, Karsten U, Hanelt D, Wiencke C (2002) Seasonal variation in ecophysiological patterns in macroalgae from an Arctic fjord. II. Pigment accumulation and biochemical defence systems against high light stress. Mar Biol 140:10871095

Altamirano M, Flores-Moya A, Figueroa F-L (2000) Long-term effects of natural sunlight under various ultraviolet radiation conditions on growth and photosynthesis of intertidal Ulva rigida (Chlorophyceae) cultivated in situ. Bot Mar 43:19-26

Apprill AM, Lesser MO (2003) Effects of ultraviolet radiation on Laminaria saccharina in relation to depth and tidal height in the Gulf of Maine. Mar Ecol Prog Ser 256:75-85

Bischof K, Hanelt D, Tüg H, Karsten U, Brouwer PEM, Wiencke C (1998) Acclimation of brown algal photosynthesis to ultraviolet radiation in Arctic coastal waters (Spitsbergen, Norway). Polar Biol 20:388-395

Bischof K, Hanelt D, Wiencke C (1999): Acclimation of maximal quantum yield of photosynthesis in the brown alga Alaria esculenta under high light and UV radiation. Plant Biol 1:435444

Bischof K, Hanelt D, Aguilera J, Karsten U, Vögele B, Sawall T, Wiencke C (2002a) Seasonal variation in ecophysiological patterns in macroalgae from an Arctic fjord. I. Sensitivity of photosynthesis to ultraviolet radiation. Mar Biol 140:10971106 
Bischof K, Kräbs G, Wiencke C, Hanelt D (2002b) Solar ultraviolet radiation affects the activity of ribulose-1,5-biphosphate carboxylase-oxygenase and the composition of photosynthetic and xanthophyll cycle pigments in the intertidal green alga Ulva lactuca L. Planta 215:502-509

Caldwell MM (1971) Solar ultraviolet radiation and the growth and development of higher plants. In: Giese AC (ed) Photophysiology. Academic, New York, pp 131-177

Caldwell MM, Robberecht R, Flint SD (1983) Internal filters: prospects for UV-acclimation in higher plants. Physiol Plant $58: 445-450$

Clendennen SK, Zimmerman RC, Powers DA, Alberte RS (1996) Photosynthetic response of giant kelp Macrocystis pyrifera (Phaeophyceae) to ultraviolet radiation. J Phycol 32:614-620

Coelho SM, Rijstenbil JW, Brown MT (2000) Impacts of anthropogenic stresses on the early development stages of seaweeds. J Aquat Ecosyst Stress Recovery 7:317-333

Dring MJ, Makarov V, Schoschina E, Lorenz M, Lüning K (1996) Influence of ultraviolet-radiation on chlorophyll fluorescence and growth in different life-history stages of three species of Laminaria (Phaeophyta). Mar Biol 126:183-191

Dummermuth AL, Wiencke C (2003) Experimental investigation of seasonal development in six Antarctic red macroalgae. Antarct Sci 15:449-457

Franklin LA, Forster RM (1997) The changing irradiance environment: consequences for marine macrophyte physiology, productivity and ecology. Eur J Phycol 32: 207-232

Garcia-Pichel F. (1994) A model for internal self-shading in planktonic organisms and its implications for the usefulness of ultraviolet sunscreens. Limnol Oceanogr 39:1704-1717

Granbom M, Pedersén M, Kadel P, Lüning K (2001) Circadian rhythm of photosynthetic oxygen evolution in Kappaphycus alvarezii (Rhodophyta): dependence on light quantity and quality. J Phycol 37:1020-1025

Han T, Kain J.M. (1996). Effect of photon irradiance and photoperiod on young sporophytes of four species of the Laminariales. Eur J Phycol 31:233-240

Hanelt D, Melchersmann B, Wiencke C, Nultsch W (1997a) Effects of high light stress on photosynthesis of polar macroalgae in relation to depth distribution. Mar Ecol Prog Ser 149:255-266

Hanelt D, Wiencke C, Nultsch W (1997b) Influence of UV radiation on photosynthesis of Arctic macroalgae in the field. J Photochem Photobiol B Biol 38:40-47

Hanelt D, Wiencke C, Karsten U, Nultsch W (1997c) Photoinhibition and recovery after high light stress in different developmental and life-history stages of Laminaria saccharina (Phaeophyta). J Phycol 33:387-395

Hanelt D, Tüg GH, Bischof K, Groß C, Lippert H, Sawall T, Wiencke C (2001) Light regime in an Arctic fjord: a study related to stratospheric ozone depletion as a basis for determination of UV effects on algal growth. Mar Biol 138:649-658

Henry BE, Van Alstyne KL (2004) Effects of UV radiation on growth and phlorotannins in Fucus gardneri (Phaeophyceae) juveniles and embryos. J Phycol 40:527-533

Herms DA, Mattson WJ (1992) The dilemma of plants: to grow or defend. Q Rev Biol 67:283-335

Huovinen PS, Oikari AOJ, Soimasuo MR, Cherr GN (2000) Impact of UV radiation on the early development of the giant kelp (Macrocystis pyrifera) gametophytes. Photochem Photobiol 72:308-313

Jacobsen S, Lüning K, Goulard F (2003) Cicadian changes in relative abundance of two photosynthetic transcripts in the marine macroalga Kappaphycus alvarezii (Rhodophyta). J Phycol 39:888-896

Johansson G, Snoeijs P (2002) Macroalgal photosynthetic responses to light in relation to thallus morphology and depth zonation. Mar Ecol Prog Ser 244:63-72

Jokela K, Leszczynski K, Visuri R (1993) Effects of Arctic ozone depletion and snow on UV exposure in Finland. Photochem Photobiol 58:559-566

Kain JM (1989) The seasons in the subtidal. Br Phycol J 24:203215
Karentz D (1994) Ultraviolet tolerance mechanisms in Antarctic marine organisms. In: Weiler CS, Penhale PA (eds) Ultraviolet radiation in Antarctica: Measurements and Biological effects (Antarctic Research Series no. 62). American Geophysical Union, Washington DC, pp 93-110

Karsten U, Bischof K, Wiencke C (2001) Photosynthetic performance of Arctic macroalgae after transplantation from deep to shallow waters followed by exposure to natural solar radiation. Oecologia 127:11-20

Lüder UH, Knoetzel J, Wiencke C (2001) Acclimation of photosynthesis and pigments to seasonally changing light conditions in the endemic Antarctic red macroalga Palmaria decipiens. Polar Biol 24:598-603

Lüder UH, Wiencke C, Knoetzel J (2002) Acclimation of photosynthesis and pigments during and after six months of darkness in Palmaria decipiens (Rhodophyta): a study to simulate Antarctic winter sea ice cover. J Phycol 38:904-913

Lüning K (1979) Growth strategies of three Laminaria species (Phaeophyceae) inhabiting different depth zones in the sublittoral region of Helgoland (North Sea). Mar Ecol Prog Ser $1: 195-207$

Lüning K (1985) Meeresbotanik: Verbreitung, Ökophysiologie und Nutzung der marine Makroalgen. Georg Thieme Verlag, Stuttgart, pp 375

Lüning K (1992) Day and night kinetics of growth rate in green, brown, and red seaweeds. J Phycol 28:794-803

Lüning K (1993) Environmental and internal control of seasonal growth in seaweeds. Hydrobiologia 260/261:1-14

Lüning K (1994a) Circadian growth rhythm in juvenile sporophytes of Laminariales (Phaeophyta). J Phycol 30:193-199

Lüning K (1994b) When do algae grow? The third founders' lecture. Eur J Phycol 29:61-67

Lüning K (2001) Circadian growth in Porphyra umbilicalis (Rhodophyta): spectral sensitivity of the circadian system. J Phycol 37:52-58

Makarov MV, Voskoboinikov GM (2001) The influence of ultraviolet-B radiation on spore resease and growth of the kelp Laminaria saccharina. Bot Mar 44:89-94

Michler T, Aguilera J, Hanelt D, Bischof K, Wiencke C (2002) Long-term effects of ultraviolet radiation on growth and photosynthetic performance of polar and cold-temperate macroalgae. Mar Biol 140:1117-1127

Müller R, Crutzen PJ, Grooß JU, Brühl C, Russel JM, Gernandt H, Mc Kenna DS, Tuck AF (1997) Severe ozone loss in the Arctic during the winter of, 1995-96. Nature 389:709-712

Pakker H, Beekman CAC, Breeman AM (2000a) Efficient photoreactivation of UVBR-induced DNA damage in the sublittoral macroalga Rhodymenia pseudopalmata (Rhodophyta). Eur J Phycol 35:109-114

Pakker H, Martins RST, Boelen P, Buma AGJ, Nikaido O, Breeman AM (2000b) Effects of temperature on the photoreactivation of ultraviolet-B-induced DNA damage in Palmaria palmata (Rhodophyta). J Phycol 36:334-341

Pavia H, Brocks E (2000) Extrinsic factors influencing phlorotannin production in the brown alga Ascophyllum nodosum. Mar Ecol Prog Ser 193:285-294

Pavia H, Cervin G, Lindgren A, Åberg P (1997) Effects of UV-B radiation and simulated herbivory on phlorotannins in the brown alga Ascophyllum nodosum. Mar Ecol Prog Ser 157:139146

Pavia H, Toth G, Åberg P (1999) Trade-offs between phlorotannin production and annual growth in natural populations of the brown seaweed Ascophyllum nodusum. J Ecol 87:761771

Poll WH van de, Eggert A, Buma AGJ, Breeman AM (2001) Effects of UV-B induced DNA damage and photoinhibition on growth of temperate marine red macrophytes: habitat-related differences in UV-B tolerance. J Phycol 37:30-37

Poll WH van de, Hanelt D, Hoyer K, Buma AGJ, Breeman AM (2002) Ultraviolet-B induced cyclobutane-pyrimidine dimer formation and repair in Arctic marine macrophytes. Photochem Photobiol 76:493-501 
Poppe F, Hanelt D, Wiencke C (2002) Changes in ultrastructure, photosynthetic activity and pigments in the Antarctic red alga Palmaria decipiens during acclimation to UV radiation. Bot Mar 45:253-261

Rex M, Harris NRP, von der Gathen P, Lehmann R, Braathen GO, Reimer E, Beck A, Chipperfield MP, Alfier R, Allaart M, O'Connor F, Dier H, Dorokhov V, Fast H, Gil M, Kyrö E, Litynska Z, Mikkelsen IS, Molyneux MG, Nakane H, Notholt J, Rummukainen M, Viatte P, Wenger J (1997) Prolonged stratospheric ozone loss in the 1995-96 Arctic winter. Nature 389:835-838

Rex M, Salawitch RJ, Harris NRP, von der Gathen P, Braathen GO, Schulz A, Deckelmann H, Chipperfield M, Sinnhuber BM, Reimer E, Alfier R, Bevilacqua R,Hoppel K, Fromm M, Lumpe J, Küllmann H,Kleinböhl A, Bremer H, König M, Künzi K, Toohey D, Vömel H, Richard E, Aikin K, Jost H, Greenblatt JB, Loewenstein M, Podolske JR, Webster CR, Flesch GJ, Scott DC, Herman R, Margitan L, Elkins JW, Ray EA, Moore FL, Hurst DF, Romashkin P, Toon GC, Sen BJJ, Wennberg P, Neuber R, Allart M, Bojkov RB, Claude H, Davies J, Davies W, Backer H, de Dier H, Dorokhov V, Fast, H, Kondo Y, Kyrö E, Litynska Z, Mikkelsen IS, Molyneux MJ, Moran E, Murphy G, Nagai T, Nakane H, Parrondo C, Ravegnani F, Skrivankova P, Viatte P, Yushkov V (2002) Chemical loss of Arctic ozone in winter 1999/2000. J Geophys Res 107, D20, 8276. DOI 10.1029/2001JD000533

Robberecht R, Caldwell MM (1978) Leaf epidermal transmittance of ultraviolet radiation and its implications for plant sensitivity to ultraviolet-radiation induced injury. Oecologia (Berl.) 32:277-287

Roleda MY, Hanelt D, Kräbs G, Wiencke C (2004a) Morphology, growth, photosynthesis and pigments in Laminaria ochroleuca (Laminariales, Phaeophyta) under ultraviolet radiation. Phycologia 43:603-613

Roleda MY, van de Poll WH, Hanelt D, Wiencke C (2004b) PAR and UVBR effects on photosynthesis, viability, growth and DNA in different life stages of two coexisting Gigartinales: implications for recruitment and zonation pattern. Mar Ecol Prog Ser 281:37-50

Roy S (2000) Strategies for the minimisation of UV-induced damage. In: de Mora S, Demers S, Vernet, M (eds) The effects of UV radiation in the marine environment. Cambridge University Press, Cambridge, pp 177-205
Schoenwaelder MEA (2002) The occurrence and cellular significance of physodes in brown algae. Phycologia 41:125-139

Setlow RB (1974) The wavelengths in sunlight effective in producing skin cancer: a theoretical analysis. Proc Nat Acad Sci USA 71:3363-3366

Solomon S (1999) Statospheric ozone depletion: a review of concepts and history. Rev Geophys 37:275-316

Stähelin J, Harris NRP, Appenzeller C, Eberhard J (2001) Ozone trends: a review. Rev Geophys 39:231-290

Starr RC, Zeikus JA (1993) UTEX - the culture collection of algae at the University of Texas at Austin. J Phycol 29 (Suppl.):1-106

Steinberg PD (1984) Algal chemical defense against herbivores: allocation of phenolic compounds in the kelp Alaria marginata. Science 223:405-406

Strömgren T, Nielsen MV (1986) Effect of diurnal variations in natural irradiance on the apical length growth and light saturation of growth in five species of benthic macroalgae. Mar Biol (Berl) 90:467-472

Suzuki L, Johnson CH (2001) Algae know the time of day: circadian and photoperiodic programs. J Phycol 37:933-942

Vincent WF, Neale PJ (2000) Mechanisms of UV damage to aquatic organisms. In: de Mora S, Demers S, Vernet M (eds) The effects of UV radiation in the marine environment. Cambridge University Press, Cambridge, pp 149-176

Vink AA, Bergen-Henegouwen JB, Nikaido O, Baan RP, Roza L (1994) Removal of UV-induced DNA lesions in mouse epidermis soon after irradiation. Photochem Photobiol 24:2531

Wiencke C (1990a) Seasonality of brown macroalgae from Antarctica- a long-term culture study under fluctuating Antarctic daylengths. Polar Biol 10:589-600

Wiencke C (1990b) Seasonality of red and green macroalgae from Antarctica- a long-term culture study under fluctuating Antarctic daylengths. Polar Biol 10:601-607

Wiencke C, Gómez I, Pakker H, Flores-Moya A, Altamirano M, Hanelt D, Bischof K, Figueroa F-L (2000) Impact of UV radiation on viability, photosynthetic characteristics and DNA of brown algal zoospores: implications for depth zonation. Mar Ecol Prog Ser 197:217-229

Wiencke C, Clayton MN, Schoenwaelder M (2004) Sensitivity and acclimation to UV radiation of zoospores from five species of Laminariales from the Arctic. Mar Biol 145:31-39 